\title{
PERBEDAAN HASIL BELAJAR IPA BIOLOGI MENGGUNAKAN MODEL PEMBELAJARAN KOOPERATIF TIPE TEAM ASSISTED INDIVIDUALIZATION DENGAN TIPE MIND MAPPING PADA SISWA KELAS VII SMP NEGERI 19 MATARAM
}

\section{THE DIFFERENCE OF SCIENCE BIOLOGY LEARNING OUTCOMES IN VII GRADE STUDENTS THROUGH THE APPLICATION OF TEAM ASISSTED INDOVIDUALIZATION WITH MIND MAPPING LEARNING MODEL AT SMPN 19 MATARAM}

\author{
Arilda Setiya Ningrum, Nur Lestari, Kusmiyati \\ Program Studi Pendidikan Biologi, Fakultas Keguruan dan Ilmu Pendidikan, Universitas Mataram \\ Jalan Majapahit No. 62 Mataram, Lombok, 83125, Indonesia \\ Email: kusmiyati.fkip@unram.ac.id
}

Diterima: 2 Januari 2018. Disetujui: 25 Maret 2018. Dipublikasikan: 31 Maret 2018

\begin{abstract}
Abstrak: Penelitian ini bertujuan untuk mengetahui perbedaan hasil belajar IPA Biologi pada siswa kelas VII menggunakan model pembelajaran tipe Team Assisted Indovidualization (TAI) dengan model pembelajaran Mind Mapping di SMPN 19 Mataram tahun ajaran 2017/2018. Jenis penelitian ini adalah penelitian komparatif. Desain penelitian yang digunakan adalah pretest-postest non-control group design. Populasinya adalah seluruh kelas VII SMP Negeri 19 Mataram. Penentuan sampel dilakukan dengan teknik simple random sampling dan diperoleh kelas VII C sebagai kelas eksperimen I dan kelas VII D sebagai kelas eksperimen II. Instrumen yang digunakan untuk mengukur hasil belajar adalah tes objektif dan tes subjektif untuk hasil belajar kognitif, lembar observasi siswa untuk hasil belajar afektif dan psikomotorik. Data yang diperoleh dianalisis dengan uji-t polled varians dengan taraf signifikansi 5\%. Data yang diuji dengan uji-t adalah data gain score. Hasil uji-t untuk data hasil belajar kognitif didapatkan bahwa $t_{\text {hitung }}>t_{\text {tabel }}$ yakni 2,16>1,99. Hasil analisis data menunjukkan terdapat perbedaan hasil belajar siswa menggunakan model pembelajaran Team Assisted Individualization (TAI) dengan model pembelajaran Mind Mapping di SMP Negeri 19 Mataram tahun ajaran 2017/2018.
\end{abstract}

Kata Kunci: Team Assisted Individualization (TAI), Mind Mapping, Hasil belajar.

\begin{abstract}
This research aimed to determine the difference of science biology learning outcomes in VII grade students through the application of Team Assisted Individualization (TAI) learning model with Mind Mapping learning model at SMPN 19 Mataram academic year 2017/2018. The type of research was a comparative research. Pretest-posttest non-control group design was used as the design of this research. The population is the entire class VII SMP Negeri 19 Mataram. Samples were determined by simple random sampling technique that has chosen VII C as experiment class I and VII D as experiment class II. Objective and subjective tests were used to measure student achievement for cognitive student achievement, student observation sheets for effective and psychomotor student achievement. The data obtained were analyzed by t-test polled variance with a significance level of $5 \%$. The data tested by the t-test is the gain score data. Result of t-test for cognitive learning has found $t_{\text {count }}>t_{\text {table }}$ that 2,16>1,99. The data analysis showed a difference in student learning result using TAI learning model with Mind Mapping learning model at SMP Negeri 19 Mataram academic year $2017 / 2018$.
\end{abstract}

Keywords: Team Assisted Individualization (TAI), Mind Mapping, Student Achievment.

\section{PENDAHULUAN}

Proses pembelajaran Ilmu Pengetahuan Alam (IPA) memerlukan pemahaman dan ketelitian terhadap materi yang diajarkan. Hal itu karena menurut Delismar dkk. [1,2] IPA mengkaji peristiwa, fakta, konsep, dan generalisasi yang berkaitan dengan alam sekitar. Salah satu bidang ilmu dasar dalam IPA adalah biologi. Fatmawati [3] menyatakan bahwa biologi merupakan ilmu yang lahir dan berkembang berdasarkan observasi dan eksperimen.

Model pembelajaran koperatif telah banyak digunakan untuk meningkatkan hasil belajar dan terbukti berhasil meningkatkan hasil belajar [3-10]. Model pembelajaran Team Assisted Individualization
(TAI) merupakan model pembelajaran yang mempunyai strategi pembelajaran penerapan bimbingan antar teman. Model pembelajaran ini menggabungkan antara pembelajaran kooperatif dan pembelajaran individu. Model pembelajaran Team Assisted Individualization (TAI) lebih dikenal dengan pembelajaran individu dalam kelompok karena, dalam pembelajaran TAI kesulitan yang dialami siswa dapat dipecahkan bersama dengan ketua serta bimbingan guru. Keberhasilan dari tiap individu ditentukan oleh keberhasilan kelompok, sehingga diperlukan kemampuan interaksi sosial yang baik antara semua anggota kelompok.

Implementasi Pembelajaran Kooperatif dalam struktur TAI ini ditunjukkan dengan siswa 
dapat bekerja sama dalam kelompok dyad (terdapat dua orang) atau triad (kelompok tiga orang). Warsono dan Hariyanto [11] mengemukakan bahwa, mereka belajar untuk menjawab sejumlah masalah atau pertanyaan yang ada dalam suatu paket pembelajaran serta diberikan kewenangan memberikan nilai kepada hasil kerja temannya dalam tim yang sama. Kemudian, mereka diberikan kuis. Hasil kuis ini dinilai oleh kelompok lain dan selanjutnya dilaksanakan tinjauan oleh salah seorang siswa dalam kelompok yang bertindak sebagai pemantau (monitor). Setelah tinjauan ini selesai dan disetujui oleh para siswa dalam kelompoknya, mereka dapat mengerjakan tes akhir (final test) dan mendapatkan skor final setelah selesai mengerjakan tes akhir. Para siswa yang memperoleh skor positif akan mendapatkan penghargaan bagi hasil karyanya.

Model pembelajaran kooperatif tipe TAI berbantuan modul efektif dalam meningkatkan hasil belajar siswa baik dari segi proses maupun hasil dibandingkan dengan metode ceramah bervariasi (ceramah, tanya jawab dan penugasan) [12]. Penerapan metode TAI lebih efektif meningkatkan hasil belajar siswa dibandingkan metode ceramah bervariasi berbantuan kartu soal [13].

Selain Model Pembelajaran Tipe TAI, Metode pembelajaran peta konsep adalah cara lain untuk menguatkan pengetahuan dan pemahaman siswa terhadap bahan-bahan yang telah dibacanya [14]. Penggunaan model pembelajaran Mind Map melibatkan kedua belahan otak, sehingga melibatkan sistem limbik (melibatkan emosi positif), yaitu dapat membuat siswa senang saat belajar karena melibatkan otak kanan [15].

Hasil penelitian lain [16] menunjukkan perbedaan signifikan prestasi belajar menulis kreatif siswa yang mengikuti strategi mind mapping dengan pembelajaran konvensional. Metode mind mapping dapat meningkatkan kualitas pembelajaran Bahasa Indonesia dan peningkatan kualitas menulis cerita pendek siswa [17]. Berdasarkan uraian di atas, peneliti merasa perlu untuk melakukan penelitian tentang perbedaan model pembelajaran Kooperatif Tipe TAI ((Team Assited Individualization) dengan model pembelajaran Mind Mapping terhadap hasil belajar IPA Biologi pada siswa kelas VII SMP Negeri 19 Mataram tahun ajaran 2017/2018.

\section{METODE PENELITIAN}

Jenis penelitian ini adalah penelitian komparatif. Penelitian ini membandingkan hasil belajar siswa menggunakan model Team Assisted Individualizatin (TAI) dan Mind Mapping. Penelitian (pengambilan data) ini telah dilaksanakan pada bulan Juli-Agustus semester ganjil tahun ajaran 2017/2018 di SMPN 19 Mataram. Variabel bebas (Independen) pada penelitian ini adalah Model pembelajaran TAI
(Team Assisted Individualization) dengan model pembelajaran Mind Mapping. Variabel terikat pada penelitian ini adalah Hasil belajar IPA Biologi Siswa. Populasi dalam penelitian ini adalah seluruh kelas VII SMPN 19 Mataram yang meliputi 6 kelas yaitu kelas VII A sebanyak 30 siswa, VII B sebanyak 31 siswa, VII C sebanyak 31 siswa, VII D sebanyak 31 siswa, VII E sebanyak 32 siswa dan VII F sebanyak 32 siswa, sehingga total dari keseluruhan adalah 187 orang siswa. Sampel penelitian diambil dengan teknik purposive samping, pengambilan sampel dari populasi dilakukan secara acak tanpa memperhatikan strata yang ada dalam populasi itu. Langkah pengambilan sampel yaitu dengan mengundi 6 kelas populasi untuk mengambil 2 kelas sampel kemudian mengundi lagi 2 kelas sampel yang diperoleh untuk menentukan kelas mana yang akan diberikan perlakuan menggunakan model Team Assisted Individualization (TAI) dan model Mind Mapping, sehingga diperoleh kelas VII C dijadikan kelas eksperimen I yang diberikan model Mind Mapping dengan jumlah siswa 31 orang dan kelas VII D dijadikan kelas eksperimen II yang diberikan model TAI dengan jumlah siswa 32 orang. Desain penelitian yang digunakan adalah Pretest-postest non-control group design.

\section{HASIL DAN PEMBAHASAN Hasil Penelitian}

Data pre-test menunjukkan bahwa nilai ratarata kedua kelas sampel sangat rendah, dimana kelas VII C dengan model Mind Mapping memperoleh rata-rata sebesar 32,1 dan kelas VII D dengan model TAI memiliki rata-rata sebesar 32,7. Nilai maksimum kelas dengan model Mind Mapping yaitu 42, sedangkan kelas dengan model TAI yaitu 44. Nilai minimum dari kelas dengan model Mind Mapping yaitu 19 dan kelas dengan TAI yaitu 20 .

Data post-test menunjukkan bahwarata-rata tes akhir kelas yang menggunakan model TAI lebih tinggi yaitu dengan nilai rata-rata 81,5 dibandingkan kelas dengan model Mind Mapping dengan nilai ratarata sebesar 77,3. Nilai maksimum kelas dengan modelMind Mappping yaitu 87 sedangkan kelas dengan model TAI yaitu 92. Nilai minimum kelas dengan model Mind Mapping yaitu 65 sedangkan kelas yang menggunakan model TAI yaitu 68 .

Perbandingan antara kelas dengan model Mind Mapping dan model TAI secara terperinci terkait hubungan antara pre-test dan post-test dapat digambarkan dalam Gambar 4.3. Berdasarkan Gambar 4.3 terlihat jelas peningkatan antara tes awal dan tes akhir baik kelas dengan model Mind Mapping maupun kelas dengan model TAI. Kelas yang menggunakan model TAImemiliki nilai yang lebih tinggi dibandingkan dengan kelas yang menggunakan model Mind Mapping. 


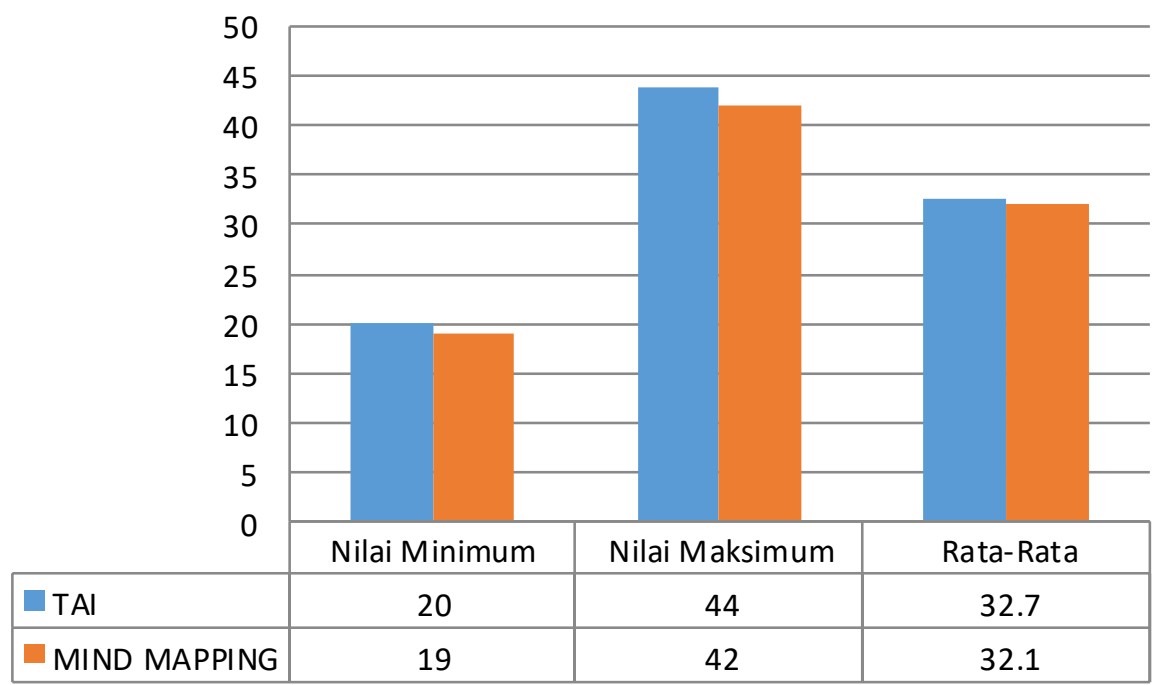

Gambar 4.1 Perbandingan Pre-Test Kelas dengan model Mind Mapping dan model Team Assisted Individualization (TAI).

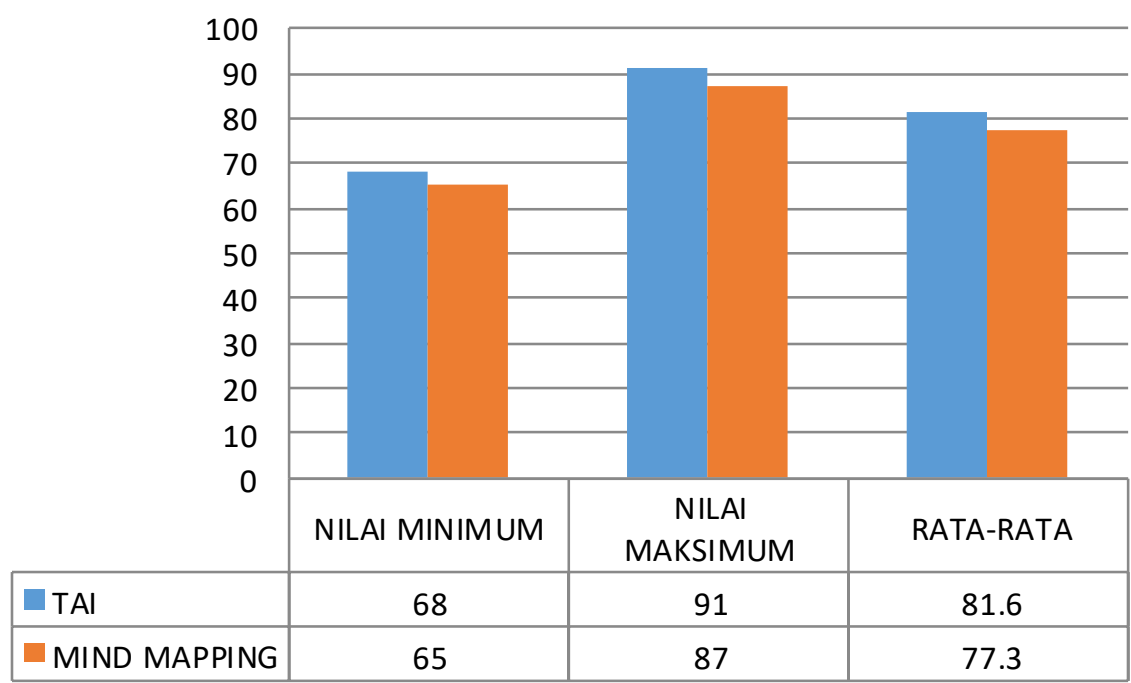

Gambar 4.2. Perbandingan Post-test Kelas dengan model Mind Mapping dan model Team Assisted Individualization (TAI).

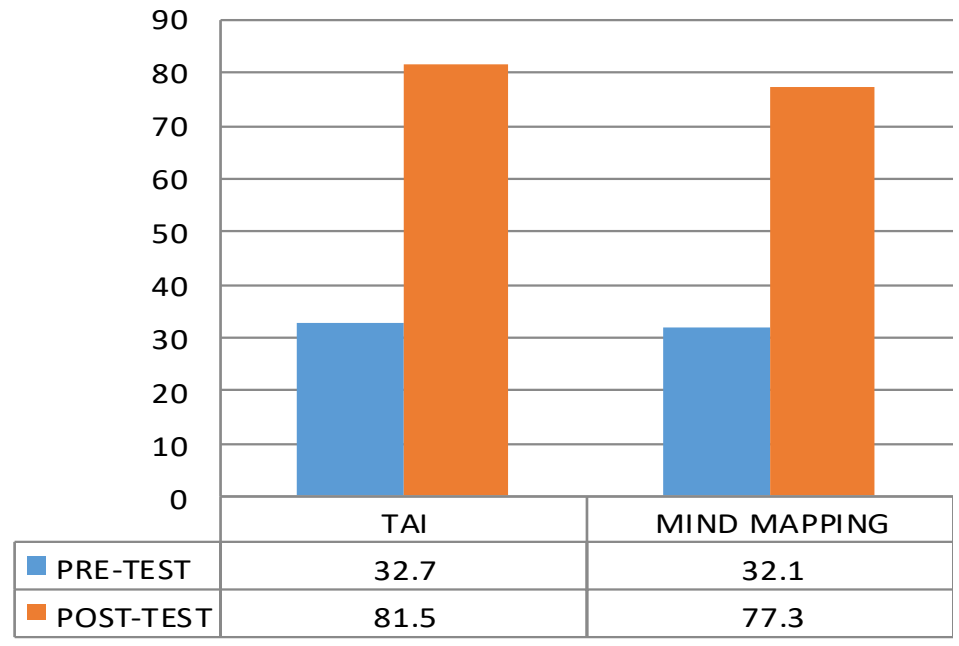

Gambar 4.3. Perbandingan nilai rata-rata Pre-test dan Post-test Kelas dengan model Mind Mapping dan model Team Assisted Individualization (TAI). 
Uji hipotesis dilakukan setelah melakukan uji persyaratan yaitu uji normalitas dan uji homogenitas data. Uji persyaratan dilakukan untuk mengetahui apakah analisis data dapat dilanjutkan atau tidak. Uji persyaratan menunjukkan bahwa data hasil belajar siswa terdistribusi normal dan varian data homogen, dikarenakan kedua syarat terpenuhi maka uji hipotesis yang digunakan yaitu uji t polled varians. Data hasil belajar kognitif yang dianalisis menggunakan uji-t ialah hasil gain score atau selisih

Penilaian afektif menggunakan lembar observasi dan setelah dianalisis diperoleh persentase nilai afektif pada kelas VII C yang menggunakan model Mind Mapping sebanyak $0 \%$ berkategori sangat kurang, 6,5\% berkategori kurang, 32,4\% kategori cukup baik, 51,6 \% berkategori baik dan 9,7\% berkategori sangat baik. Kelas VII D dengan penerapan model TAI sebanyak $0 \%$ berkategori sangat kurang, 6,3 \%kurang, $25 \%$ cukup baik, $53,1 \%$ berkategori baik, dan sebanyak 15,6\% berkategoti sangat baik.

Tabel 4.1 menunjukkan bahwakategori yang memiliki persentase paling tinggi pada kelas model Mind Mapping maupun kelas model TAI yaitu pada kategori baik, persentase kedua kelas sampel berturut-turut $51,6 \%$ dan $53,1 \%$. Penilaian hasil belajar psikomotorik pada kelas yang menggunakan model Mind Mapping diperoleh $0 \%$ berkategori sangat kurang, 12,9\% berkategori kurang, 25,80\% berkategori cukup baik, 41,9\% berkategori baik, dan $19,4 \%$ beraktegori sangat baik. Kelas yang menggunakan model TAI diperoleh $0 \%$ berkategori sangat kurang, 6,3\% berkategori kurang, $25 \%$ berkategoroi cukup baik, 43,8 \% berkategori baikdan $25 \%$ berkategori sangat baik.

Tabel 4.2 menunjukkan bahwa kategori yang memiliki persentase paling tinggi pada kelas model Mind Mapping maupun kelas model TAI yaitu pada kategori Baik, persentase kedua kelas sampel berturut-turut $41,9 \%$ dan $43,8 \%$.Keterlaksanaan proses pembelajaran diukur dengan menggunakan lembar observasi keterlaksanaan RPP yang diamati oleh observer. Pengamatan dilakukan untuk melihat apakah proses pembelajaran yang berlangsung sesuai dengan yang tercantum pada RPP.

Tabel 4.3 menunjukkan bahwa persentase kedua kelas sampel sangat baik pada ketiga pertemuan. Kelas dengan model pembelajaran Mind Mapping pada pertemuan pertama dan ketiga nilainya masing-masing 100 dengan skor maskimal berturutturut 23 dan 21, sedangkan untuk pertemuan kedua nilainya sebesar 90,5 dengan skor maskimal 21, yang berarti 2 kegiatan tidak dilakukan. Pada kelas dengan model pembelajaran TAI menunjukkan pada pertemuan pertama nilainya sebesar 100 , sedangkan pertemuan kedua dan ketiga sebesar 95,5. Hal ini menunjukkan keterlaksaan RPP pada kedua kelas termasuk dalam kategori sangat bagus. dari nilai post-test dan pre-test siswa. Hasil uji homogenitas gain score pada kedua kelas didapatkan bahwa $F_{\text {hitung }}<F_{\text {tabel }}$ yaitu $0,5<1,82$ maka data kedua kelas dinyatakan homogen. Hasil uji t dengan taraf kesalahan 0,05 , diperoleh nilai $t_{\text {hitung }}>t_{\text {tabel }}$, yaitu 2,2> 1,99, hal ini menunjukkan bahwa ada perbedaan antara hasil belajar IPA Biologi siswa kelas VII menggunakan model TAI dan model Mind Mapping di SMP Negeri 19 Mataram tahun ajaran 2017/2018.

Analisis hasil belajar menunjukkan bahwa siswa yang mengikuti pembelajaran dengan model pembelajaran TAI memiliki nilai rata-rata yang lebih tinggi sebesar 81,5 dari rata-rata awal hasil belajar IPA Biologi siswa yaitu sebesar 32,7, sedangkan siswa yang mengikuti pembelajaran dengan model pembelajaran Mind Mapping memiliki nilai rata-rata 77,3 dari rata-rata awal hasil belajar IPA Biologi siswa yaitu sebesar 32,2. Hasil uji hipotesis data hasil belajar siswa menunjukkan nilai $t_{\text {hitung }}$ sebesar 2,2 lebih besar dari $t_{\text {tabel }}$ yaitu $1,99(2,2>1,99)$. Data yang diperoleh menunjukkan model TAI memberikan hasil belajar yang lebih baik daripada model Mind Mapping. Selisih rata-rata kelas yang menggunakan model TAI adalah 48,9. Selisih rata-rata tersebut lebih tinggi dibandingkan dengan kelas yang menggunakan model Mind Mapping yaitu 45,1.

Pembelajaran TAI memiliki keunggulan yaitu; adanya seorang asisten dalam setiap kelompoknya. Dalam setiap diskusi kelompok, seorang asisten ikut bertanggung jawab terhadap teman sekelompoknya yang kurang paham tentang materi yang diajarkan. Adanya sumbangan yang diberikan oleh seorang asisten kepada teman satu kelompoknya dapat membuat siswa yang lemah terbantu memahami materi dan belajar lebih baik lagi, karena ketika siswa bertanya ke asisten akan lebih mudah dan tidak malu mengutarakan pertanyaannya dibandingkan kepada guru; guru terbantu dengan adanya asisten, karena dengan adanya asisten pengelolaan dan pengorganisasian kelas menjadi lebih mudah; metode TAI ini menitikberatkan pada keaktifan siswa dalam belajar, sehingga akan tercipta interaksi yang lebih intens diantara siswa yang dapat menyebabkan siswa tidak mudah bosan dalam belajar; mengurangi perilaku yang menggangu dan konflik antar siswa selama proses pembelajaran; penggunaan waktu mengajar guru lebih tercurah kepada kelompok. Kelebihan TAI juga diungkapkan oleh Mahanani dan Slavin [11] yang menyatakan adanya sumbangan yang diberikan oleh asisten kepada anggota kelompok dapat membuat mereka lebih mudah dalam memahami materi.

Penerapan model pembelajaran pada kedua kelas sampel juga mempengaruhi sikap (afektif) siswa. Berdasarkan hasil analisis lembar observasi afektif siswa, model pembelajaran TAI mempunyai 
persentase pada kategori baik yaitu sebesar 53,1\% dan sangat baik $15,7 \%$, sedangkan kelas dengan penerapan model pembelajaran Mind Mapping mempunyai persentase sebesar $51,6 \%$ pada kategori baik dan 9,7 \% pada kategori sangat baik. Hasil analisis tesebut menunjukkan bahwa model pembelajaran TAI dapat lebih baik dalam meningkatkan aspek sikap siswa daripada model Mind Mapping.

Tabel 4.1. Perbandingan Hasil Belajar Afektif

\begin{tabular}{cccccc}
\hline \multirow{2}{*}{ Rentang } & \multirow{2}{*}{ Kategori } & \multicolumn{2}{c}{ Model Mind Mappping } & \multicolumn{2}{c}{ Model TAI } \\
\cline { 3 - 5 } & & Jumlah & Persentase & Jumlah & Persentase \\
\hline $86-100$ & Sangat Baik & 3 & $9,7 \%$ & 5 & $15,6 \%$ \\
$76-85$ & Baik & 16 & $51,6 \%$ & 17 & $53,1 \%$ \\
$60-75$ & Cukup Baik & 10 & $32,3 \%$ & 8 & $25 \%$ \\
$55-59$ & Kurang & 2 & $6,5 \%$ & 2 & $6,3 \%$ \\
$\leq 54$ & Sangat Kurang & 0 & $0 \%$ & 0 & $0 \%$ \\
Total & & 31 & $100 \%$ & 32 & $100 \%$ \\
\hline
\end{tabular}

Tabel 4.2. Perbandingan Hasil Belajar Psikomotorik

\begin{tabular}{cccccc}
\hline \multirow{2}{*}{ Rentang } & \multirow{2}{*}{ Kategori } & \multicolumn{2}{c}{ Model Mind } & \multicolumn{2}{c}{ Model TAI } \\
& & Jumlah & Persentase & Jumlah & Persentase \\
\hline $86-100$ & Sangat Baik & 6 & $19,4 \%$ & 8 & $25,0 \%$ \\
$76-85$ & Baik & 13 & $41,9 \%$ & 14 & $43,8 \%$ \\
$60-75$ & Cukup Baik & 8 & $25,8 \%$ & 8 & $25,0 \%$ \\
$55-59$ & Kurang & 4 & $12,9 \%$ & 2 & $6,3 \%$ \\
$\leq 54$ & Sangat Kurang & 0 & $0,0 \%$ & 0 & $0,0 \%$ \\
Total & & 31 & $100 \%$ & 32 & $100 \%$ \\
\hline
\end{tabular}

Tabel 4.3 Persentase Keterlaksanaan Proses Pembelajaran

\begin{tabular}{lcccccc}
\hline \multirow{1}{*}{ Kriteria Penilaian } & \multicolumn{3}{c}{ Kelas Eksperimen I } & \multicolumn{4}{c}{ Kelas Eksperimen II } \\
& Pertemuan & Pertemuan \\
Jumlah Pernyataan & 23 & 21 & 21 & 23 & 22 & III \\
Jumlah Skor & 23 & 19 & 21 & 23 & 21 & 21 \\
Skor Maksimal & 23 & 21 & 21 & 23 & 22 & 22 \\
Nilai & 100 & 90,5 & 100 & 100 & 95,5 & 95,5 \\
Kategori & SB & SB & SB & SB & SB & SB \\
\hline
\end{tabular}

\section{*Keterangan: $\mathrm{SB}=$ Sangat Bagus}

Selain aspek afektif, kedua model pembelajaran juga dapat meningkatkan hasil belajar aspek psikomotrik. Hasil analisis menunjukkan aspek psikomotorik yang paling tinggi yaitu pada kategori baik dimana pada kelas dengan penerapan model pembelajaran TAI lebih tinggi yaitu 43,8\% dibandingkan kelas dengan penerapan model pembelajaran Mind Mapping yaitu sebesar 41,9\%. Kelebihan-kelebihan yang dimiliki oleh model TAI dalam mempengaruhi sikap dan keterampilan belajar siswa antara lain meningkatkan sikap tanggung jawab, kerjasama, dan mengembangkan keterampilan siswa dalam diskusi serta memecahkan masalah pada proses belajar. Sesuai dengan hasil analisis data diatas, Fitriani [19] mengatakan model pembelajaran TAI lebih memotivasi siswa untuk saling membantu anggota`kelompoknya sehingga tercipta semangat dalam sistem kompetisi dengan lebih mengutamakan peran individu tanpa mengorbankan aspek kooperatif.

Model pembelajaran TAI menggabungkan antara pembelajaran kelompok dan individu. Sebelum diskusi secara individu siswa diberikan materi untuk dipelajari. Saat diskusi siswa sudah memiliki pemahaman dari materi yang akan dipelajari. Siswa sangat antusias dalam mengemukakan pendapat mereka di dalam kelompok saat diskusi untuk menyelesaikan masalah yang diberikan oleh guru. Hal tersebut menyebabkan proses pembelajaran lebih menarik dan tidak monoton, karena selama proses pembelajaran berlangsung, secara kelompok siswa 
dituntut mencari jawaban dari pertanyaan-pertanyaan yang diberikan guru. Jawaban kemudian didiskusikan dalam kelompok sehingga siswa lebih memahami materi yang diajarkan. Model pembelajaran TAI ini berdampak baik terhadap peningkatan hasil belajar IPA Biologi siswa dan terjalin interaksi yang baik antar siswa, sehingga proses pembelajaran lebih menyenangkan. Model pembelajaran TAI dapat meningkatkan hasil belajar. Model pembelajaran TAI membuat siswa mempunyai semangat belajar yang tinggi dan juga dapat berkomunikasi dengan baik dengan temantemannya dalam satu kelompok. Pembelajaran dengan model pembelajaran TAI membuat siswa lebih banyak mempunyai kesempatan untuk menemukan sendiri konsep-konsep melalui kerjasama antar anggota kelompok, sehingga pembelajaran lebih bermakna dan kemudian siswa dapat memahami materi dengan baik [20-22]

Model pembelajaran TAI memerlukan waktu yang cukup panjang selain itu siswa yang lemah cenderung bergantung pada siswa yang pintar. Selama proses pelaksanaan penelitian dengan menggunakan model TAI, hal tersebut dapat teratasi. Dimana dengan adanya hasil tes awal yang diberikan, didapatkan ketua kelompok yang mempunyai kemampuan lebih tinggi yang dapat membantu teman-temannya yang lemah di dalam kelompoknya, sehingga waktu yang dibutuhkan guru lebih sedikit untuk membimbing siswa secara individual. Selain itu, guru memberikan tes di akhir proses pembelajaran secara individual sehingga siswa yang lemah juga diharuskan memahami materi.

Berbeda dengan model pembelajaran TAI pada model pembelajaran Mind Mapping di dalam pembagian kelompok tidak terdapat ketua kelompok yang mempunyai kemampuan akademik lebih tinggi dari anggota kelompok lainnya, akan tetapi model pembelajaran Mind Mapping juga mempunyai kelebihan-kelebihan, menurut Buzan [15], Mind Map akan membantu siswa mudah mengingat sesuatu, mengingat fakta, angka dan rumus dengan mudah. Selain itu juga dapat meningkatkan motivasi dan konsentrasi serta mengingat dan menghafal menjadi lebih cepat. Beberapa kelebihan model Mind Mappping di atas dapat meningkatkan hasil belajar IPA Biologi siswa jika dilihat dari rata-rata pre-test yaitu sebesar 32,1 dan post-test sebesar 77,2 dimana rata-rata hasil belajar dapat meningkat sebesar 45,1. Hasil penelitian lain menunjukkan bahwa model pembelajaran Mind Mapping dapat meningkatkan rata-rata hasil belajar. Tetapi, peningkatan hasil belajar dengan penerapan model Mind Mapping masih kurang jika dibandingkan dengan peningkatan hasil belajar oleh model pembelajaran TAI yaitu dengan selisih rata-rata sebesar 48,9 [23, 16, 24]

Mind Mapping adalah cara mencatat yang kreatif, efektif, dan secara harfiah akan “memetakan" pikiran-pikiran kita. Mind Mapp membuat seseorang yang hendak menulis berhubungan dengan pikiran-pikiran bawah sadar sebelum menulis. Dengan melibatkan permainan gambar dan warna atau pola, peta pikiran membuat pelajaran lebih berkesan [25, 26]). Berbeda dengan hal tersebut, selama proses pembelajaran siswa yang menggunakan model pembelajaran Mind Mapping cenderung tidak memahami materi sebelum membuat peta knsep yang menyebabkan materi yang dipelajari kurang berkesan. Beberapa faktor yang menyebabkan Mind Mapping kurang dalam meningkatkan hasil belajar IPA Biologi siswa daripada menggunakan model pembelajaran TAI yang terlihat selama proses pembelajaran berlangsung yaitu; siswa cenderung bingung dan kurang mengerti dalam membuat peta konsep untuk pemecahan masalah yang diberikan oleh guru; hanya siswa yang aktif saja yang cenderung bertanya saat pembelajaran berlangsung guna menyelesaikan masalah yang diberikan, sedangkan siswa yang kurang aktif hanya menunggu jawaban dari temannya yang lebih aktif; pemecahan masalah dengan menggunakan peta konsep sangat bervariasi dan bebas, sehingga siswa kurang terfokus dalam menulis jawaban dari permasalahan yang diberikan.

\section{KESIMPULAN}

Berdasarkan hasil penelitian dan pembahasan, dapat disimpulkan bahwa ada perbedaan antara hasil belajar IPA Biologi pada siswa kelas VII menggunakan model Mind Mapping dengan siswa yang belajar menggunakan model Team Assisted Individualization (TAI) di SMP Negeri 19 Mataram. Hasil belajar IPA Biologi pada kelas yang menggunakan model TAI lebih tinggi dibandingkan dengan kelas yang menggunakan model Mind Mapping.

\section{DAFTAR PUSTAKA}

1. Huda, K., Kirana, T., \& Soetjipto, S. (2017). Penerapan Model Pembelajaran Kooperatif Tipe TAI (Team Assisted Individualization) Dengan Teknik Tutor Sebaya Dalam Pembelajaran Biologi SMA. JPPS: Jurnal Penelitian Pendidikan Sains, 4(2), 525-534.

2. Helmahria, H., Hamid, A., \& Sunarti, S. (2017). Meningkatkan Keterampilan Proses Sains Siswa Dengan Pendekatan Brain Based Learning. Quantum (Jurnal Inovasi Pendidikan Sains), 8(1), 36-42.

3. Hirzi, R. H., Sripatmi, S., \& Hapipi, H. (2015). Penerapan model pembelajaran kooperatif tipe snowball throwing pada pembelajaran segiempat untuk meningkatkan aktivitas dan prestasi belajar siswa smpn 1 lingsar kelas vii-1 
tahun pelajaran 2012/2013. Jurnal Pijar MIPA, 10(1).

4. Raksun, A. (2009). Implementasi Pembelajaran Kooperatifuntuk Meningkatkan Motivasi Dan Hasil Belajar Mahasiswa Program Studi Pendidikan Fisikafkipuniversitas Mataram Padamatakuliah Biologi Dasar. Jurnal Pijar MIPA, 4(1).

5. Yulianti, R., Muntari, M., \& Haris, M. (2015). Pengaruh model pembelajaran kooperatif tipe two stay two stray (tsts) dengan pendekatan brain-based learning terhadap hasil belajar kimia materi pokok struktur atom dan sistem periodik unsur pada siswa kelas $\mathrm{x}$ sman 1 kediri. Jurnal Pijar MIPA, 10(1).

6. Aini, Z., Ramdani, A., \& Raksun, A. (2018). Perbedaan Penguasaan Konsep Biologi Dan Kemampuan Berpikir Kritis Siswa Kelas X Pada Penerapan Model Pembelajaran Kooperatif Tipe Group Investigation Dan Guided Inquiry di MAN 1 Praya. Jurnal Pijar Mipa, 13(1), 19-23.

7. Gayatri, I. G. A. S., Jekti, D. S. D., \& Jufri, A. W. (2013). Efektifitas pembelajaran berbasis masalah (PBM) dan strategi kooperatif terhadap kemampuan menyelesaikan masalah dan hasil belajar kognitif biologi ditinjau dari kemampuan akademik awal siswa kelas X SMA Negeri 3 Mataram. Jurnal Pijar Mipa, 8(2).

8. Kurniati, N., \& Turmuzi, M. (2017). Penerapan Strategi Pembelajaran Kooperatif Tipe Cooperative Script Pada Perkuliahan Program Linier Untuk Meningkatkan Aktivitas Dan Prestasi Belajar Mahasiswa Semester Iv Program Studi Pendidikan Matematika FKIP Universitas Mataram. Jurnal Pijar Mipa, 11(2).

9. Ishak, M., Jekti, D. S. D., \& Sridana, N. (2017). Pengaruh Penerapan Pendekatan Saintifik Menggunakan Model Pembelajaran Discovery Dan Kooperatif Tipe Stad Terhadap Kemampuan Berpikir Kreatif Peserta Didik SDN 13 Ampenan. Jurnal Pijar Mipa, 12(1).

10. Bayuaji, P., Hikmawati, H., \& Rahayu, S. (2017). Pengaruh Model Pembelajaran Kooperatif Tipe Student Facilitator And Explaining (Sfae) Dengan Pendekatan Saintifik Terhadap Hasil Belajar Fisika. Jurnal Pijar Mipa, 12(1).

11. Warsono dan Hariyanto. 2012. Pembelajaran Aktif. Teori dan Asesmen. Bandung.
12. Sari, H., Yeni, L. F., \& Wahyuni, E. S. (2017). Efektivitas Model Pembelajaran Kooperatif Disertai Mind Mapping terhadap Hasil Belajar Materi Ekosistem Kelas X. Jurnal Pendidikan dan Pembelajaran Untan, 6(4).

13. Fatimah, N. F., Saputro, S., \& Setyowati, W. A. E. (2017). Penerapan Model Pembelajaran Kooperatif Team Assisted Individualization (Tai) Dilengkapi Lembar Kerja Siswa (Lks) Berbasis Hierarki Konsep Untuk Meningkatkan Interaksi Sosial Dan Prestasi Belajar Siswa Pada Materi Redoks Kelas X. 4 SMA Negeri 1 Ngemplak. Jurnal Pendidikan Kimia, 6(1), 6975 .

14. Suprijono, Agus. 2009. Cooperative Learning. Teori dan Aplikasi Paikem. Surabaya : Pustaka Pelajar.

15. Buzan, Tony. 2007. Alih Bahasa Susi Purwoko. Buku Pintar Mind Map. Jakarta: PT. Gramedia Pustaka Utama.

16. Maryani, N.W., A.A.I.N. Marhaeni, M. Sutama. 2013. Pengaruh Implementasi Strategi Mind Mapping Terhadap Prestasi Belajar Menulis Kreatif Ditinjau Dari Kreativitas Siswa. eJournal Program Pascasarjana Universitas Pendidikan Ganesha Jurusan Pendidikan Dasar (Volume 3 Tahun 2013).

17. Latifah, R., Latifah, R., Hidayat, A., \& Hidayat, A. (2017). Penerapan Model Pembelajaran Cooperatif Integrated Reading and Composition (CIRC) dengan Mind Mapping terhadap Kemampuan Berpikir Kritis Siswa Kelas XI IPA SMAN 1 Bojongsoang Pada Materi Sistem Ekskresi (Doctoral dissertation, UIN Sunan Gunung Djati Bandung).

18. Slavin, Robert. E. 1995. Cooperative Learning: Theory Research And Practice. Boston: Allyn and Balon.

19. Fitriani, I. 2013. Peningkatan Kualitas Pembelajaran Pkn Melalui Model Team Assisted Individualization (TAI) Dengan Media Audivisual Pada Siswa Kelas SDN Bringin 02 Kota Semarang. Fitriani, I. 2013. Peningkatan Kualitas Pembelajaran Pkn Melalui Model Team Assisted Individualization (TAI) Dengan Media Audivisual Pada Siswa Kelas SDN Bringin 02 Kota Semarang. Semarang: Universitas Mataram (Skripsi).

20. Alpenli, A. (2017). Pengaruh Model Pembelajaran Kooperatif Tipe Team Assisted Individualization (Tai) Modifikasi Problem Based Learning (Pbl) Terhadap Pemahaman Konsep Matematis Ditinjau Dari Kemampuan 
Awal Matematis Peserta Didik Kelas Viii MTsN 1 Pringsewu Tahun Pelajaran 2016/2017 (Doctoral dissertation, UIN Raden Intan Lampung).

21. Sulman, N. (2017). Komparasi Keefektifan Model Kooperatif Tipe Team Assisted Individualization Dan Tipe Think Pair Share Dengan Pendekatan Saintifik Dalam Pembelajaran Matematika Pada Siswa Kelas VII SMP Negeri 3 Salomekko Kabupaten Bone (Doctoral dissertation, Pascasarjana).

22. Tarim, K.., Akdeniz, F. 2008. The Effects Of Cooperative Learning On Turkish Elementary Students' Mathematics Achievement And Attitude Towards Mathematics Using T.A.I. And S.T.A.D. Methods. Educational Studies in Mathematics, 67, 1. 77-91

23. Andika, I A Riska Wikantary, I Km Ngurah W., I G A Agung S. A., (2015). Penerapan Mind Mapping Dalam Pendekatan Saintifik Untuk Meningkatkan Hasil Belajara Pkn Dan Pengetahauan Metakognitif Tema Cita- Citaku Pada Siswa Kelas IVa SD Negeri 1 Tonja. eJournal PGSD Universitas Pendidikan Ganesha Jurusan PGSD, 3. 1.

24. Imaduddin, Muhammad Chomsi dan Unggl Haryanto Nur Utomo. (2012). Efektifitas Metode Mind Mapping Untukmeningkatkan Prestasi Belajar Fisika pada Siswa Kelas VIII. Humanitas, Vol. IX No.1 Januari 2012.

25. Lestari, W. A. U., R. Wakhid A., Arif M., (2012). Penggunaan Mind Mapping Untuk Meningkatkan Hasil Belajar Pada Siswa MTs Negeri Purworejo. Radiasi.1, l.1.

26. Sari, H., Yeni, L. F., \& Wahyuni, E. S. (2017). Efektivitas Model Pembelajaran Kooperatif Disertai Mind Mapping terhadap Hasil Belajar Materi Ekosistem Kelas X. Jurnal Pendidikan dan Pembelajaran Untan, 6(4). 